\title{
Challenges of Strategic Issue Management Practices by Savings and Credit Cooperative Societies in Mombasa County, Kenya
}

\author{
Boniface Itevete Lwova \\ University of Nairobi
}

\begin{abstract}
Ansoff and McDonnell (1990) define Strategic Issues as forthcoming developments, either inside or outside of the organization that are likely to have an important impact on the ability of the enterprise to meet its objectives. Despite of their fundamental socio-economic role in Kenya, most savings and credit cooperative societies (Saccos), also hereby referred to as cooperatives, are faced with a number of challenges, such as: traditional products, leadership and governance issues, capital base requirement, taxation, Information and Communications Technology, regulation and supervision, developing competitive business models, demand for loans, nonremittance of fees by members, forgery, HIV/AIDS and outreach issues. Thus the central challenge for Saccos is to find constructive ways to build and retain competitive advantages in the market place. In a bid to enhance cooperatives' performance, this study was destined to identify some challenges facing strategic issue management practices by cooperatives in Mombasa County. The findings revealed that cooperatives experience a myriad of challenges hence need to practice Strategic Issue Management.
\end{abstract}

Keywords: Strategic Issues, Strategic Issue Management (SIM), Saccos.

DOI: $10.7176 / \mathrm{EJBM} / 12-28-01$

Publication date:October $31^{\text {st }} 2020$

\subsection{INTRODUCTION}

This study was deemed necessary because business environments are full of surprises and instabilities the world over. Such instabilities include: political instability, traditional products, competition and capital base to mention but a few. Broadly speaking, issue management attempts to minimize surprises which accompany social and political change by serving as an early warning system for potential and environmental threats and attempts to promote more systematic and effective responses to particular issues by serving as a coordinating and integrating force within the corporation (Mkamunduli, 2005).

Cooperatives in Kenya's turbulent business environment have faced critical moments. Despite of their fundamental socio-economic role in Kenya, most cooperatives are faced with a number of challenges, such as: traditional products, leadership and governance issues, capitalization, taxation, Information and Communications Technology, regulation and supervision, developing competitive business models, demand for loans, nonremittance of fees by members, forgery, HIV/AIDS and outreach issues. These among others have forced cooperatives managers to pause, ponder and devise ways to strengthen their enterprises.

Hence strategic management is a level of managerial activity under setting goals and over tactics to minimize challenges faced by cooperatives.

\subsection{OBJECTIVES OF THE STUDY}

This study was guided by the following objective:

i) What are the challenges of Strategic Issue Management Practices by cooperatives?

\subsection{METHODOLOGY}

This research adopted a survey research design. The choice was necessitated by the descriptive nature of typically quantitative data collected which was to be cross-sectional and therefore did not favor case study. In addition, a survey was chosen because the researcher's main aim was to get comparable data from across the study units so as to discover similarities and differences in their practices (Cooper and Schindler, 2008). The survey method therefore allowed an in-depth and complete investigation of all the cooperatives in Mombasa County.

It also allowed for comparative analysis in order to obtain rational conclusions. An extension of the survey method known as survey via personal interview (meaning a two way communication initiated by an interviewer to obtain information from a participant: face to face, phone or internet) was also adopted.

The population of study was all Saccos in Mombasa County. According to the list obtained from the District Cooperatives Officer office in Mombasa, there were a hundred and twenty nine registered and active Saccos in Mombasa County, Kenya as at $14^{\text {th }}$ June 2013. This had increased from a hundred and twenty in 2010 when Owino (2011) carried his research, signifying a 7.5\% growth.

Primary data was collected using self-administered questionnaires (see Appendix 1). This was necessitated by the fact that all the cooperatives surveyed in Mombasa County were accessible. The data was coded and checked for any errors and omissions. Responses from the questionnaires were tabulated, coded and descriptive statistics 
used. Descriptive statistics are statistical measures used to depict the center, spread and shape of distribution of findings. Statistical Package for Social Sciences (SPSS) was utilized to analyze the variables.

Tables, mean, standard deviation and percentages were used to summarize the data. The tables were summarized as a percentage of the thirty four out of the seventy respondents. This data is meant to give a picture of the kind of challenges of SIM practices by cooperatives in Mombasa County.

\subsection{LITERATURE REVIEW}

Strategy can be seen as the building of defenses against competitive forces, or as the finding of positions in the industry where competitive forces are weakest. For the modern executive to achieve desired results, it's not enough to respond by managing internal activities of the firm only but also the firm's remote environment. By so doing, the firm will enhance its growth, profitability and affirm its social legitimacy. To be able to effectively deal with the discontinuous and surprising environment, organizations should embrace Strategic Issue Management Systems (SIMS) to enhance their capacity and to adapt and to learn (Xolile, 2004).

Hesterly and Barney (2008) mentioned that the proponents of Strategic Issue Management assert as unique in the following ways: It is proactive rather than reactive, it allows companies to intercept problems at an early stage and it requires application of substantial empirical, qualitative and quantitative analysis to solve corporate planning problems.

The nature of strategic response of the firm enables it to reduce adverse effect or make the firm miss an opportunity. Being aware and finding ways to solve novel and recurrent challenges by Saccos is critical for success. The firms should therefore be able to anticipate, create and respond effectively and efficiently to changes and challenges in the external and internal environment to increase profitability.

\subsection{Savings and Credit Co-operative Societies in Mombasa, Kenya}

Iriga (2009) defines a cooperative as an autonomous association of persons united voluntarily to meet their common economic, social and cultural needs and aspirations through a jointly-owned and a democratically controlled enterprise. While the cooperative movement had proved to be a formidable vehicle for wealth creation among its members prior to, and after independence in Kenya, developments in the environment are posing a danger to sustainability.

In the early 1990s, Kenya experienced difficult economic times forcing commercial banks to demand higher minimum operating balances for individual accounts to sustain their businesses. Cooperatives became popular among employed persons who had been unable to maintain or operate bank accounts and they responded by introducing a Front Office Service Activity (FOSA) which offered quasi banking services at competitive rates.

Mombasa County thrives in the cooperative movement sector activities. It has a total of 129 active cooperative societies. The total membership of active cooperatives is 35,882 shareholders with a total turnover of Ksh.1,057,831,845 and total share capital and deposit of Ksh.3,882,055,698. The figures give more reasons why it is an economic hub worth studying at this point in time.

\subsection{Challenges of Strategic Issue Management}

Strategic Issue Management cannot be exercised without a share of its challenges. According to Ansoff and McDonnell (1990), installation and acceptance of SIM is not likely to be simple. Right from planning/formulation and implementation of SIM, challenges do occur normally at certain stages. Limiting funds to support SIM is one of the greatest challenges facing many organizations. Lack of funding therefore may make the management feel that SIM is not taken seriously, thus may engage in more of reacting to emergent issues in environment rather than planning in advance; hence compromising competitive advantage.

Learning organizations have to look for ways of accommodating varying opinions and focusing on common goals to avoid aborting opinions that could impact on an organization.

Resistance to change is another common challenge in SIM especially at the implementation stage. Resistance comes in because SIM requires real time systems. Refusal to take charge is frequently coupled with a mentality problem, a refusal by top management to accept new and unfamiliar issues as relevant to the enterprise.

Refusal of the top management group to submit itself to the discipline of SIM can be a taunting challenge. But if top management pay a lip service to SIM, it will not work.

\subsection{REPORT OF FINDINGS AND ANALYSIS}

\subsection{Challenges of Strategic Issue Management}

The main objective of this study was to establish challenges faced by cooperatives in Mombasa County in Kenya as they endeavored to practice SIM to gain competitive advantage and ensure survival into the future. The researcher sought to receive information on whether cooperatives in Mombasa County encountered the challenges as indicated in Table 1.0 below. The respondents were requested to indicate by rating each of the challenges hypothesized on a Likert-scale ranging from one - for (Not at all) to five - for (Very High). The responses' mean 
scores were computed as in Table 1.0 below.

Table 1.0 Challenges of Strategic Issue Management

\begin{tabular}{|l|c|c|}
\hline Challenges affecting SIM & $\begin{array}{c}\text { Mean } \\
\text { Score }\end{array}$ & $\begin{array}{c}\text { Standard } \\
\text { Deviation }\end{array}$ \\
\hline Business location & 2.64 & 0.81 \\
\hline Availability of financial resources & 3.48 & 0.03 \\
\hline Adequate management competence & 3.23 & 0.22 \\
\hline Government policies & 4.17 & 0.72 \\
\hline Resistance to change & 2.73 & 0.72 \\
\hline Constant changes in customer needs/demands & 3.86 & 0.41 \\
\hline Implementation time frame & 3.89 & 0.44 \\
\hline Technology & 3.75 & 0.30 \\
\hline Competition & 4.31 & 0.86 \\
\hline Level of knowledge of employees & 3.67 & 0.22 \\
\hline Ambiguity in vision and/or mission statement & 3.13 & 0.32 \\
\hline Communication & 3.44 & 0.01 \\
\hline Diversity (gender, ethnicity, status) & 2.57 & 0.88 \\
\hline $\begin{array}{l}\text { Objective of the cooperative (Profit maximization, social responsibility, market } \\
\text { leadership, quality leadership and survival) }\end{array}$ & 3.09 & 0.36 \\
\hline Economic instability/recession & 3.95 & 0.50 \\
\hline Foreign currency instability (Dollar) & 3.28 & 0.17 \\
\hline Grand Mean & $\mathbf{3 . 4 5}$ & \\
\hline
\end{tabular}

Source: Research Data

The findings as shown in table 1.0 above imply that the leading challenges of Strategic Issue Management were competition, government policies and economic instability/recession at mean scores of 4.31, 4.17 and 3.95, respectively. The findings also indicate that the least challenging factors affecting SIM were diversity (gender, ethnicity and status), business location and resistance to change with mean scores of 2.57, 2.64 and 2.73 respectively. According to (Owino, 2011) location was regarded as a unique resource that was not easy to imitate. Resource-based view of strategic management (Amit and Schoemaker, 1993; Barney, 1986, 1991) examine the resources and capabilities of firms that enable them to generate above-normal rates of return and sustainable competitive advantage. Thus competition is a major challenge for majority of cooperatives in fight for survival.

The researcher inferred that most cooperatives were near the base of their shareholders' employment; and some of those that were not comfortable with their location, point in case-Washa Sacco housed at Ralli house, were either making efforts to acquire land/plot, better premises or engaging in intensive advertisement to create awareness. All these were to reduce costs like rent and to make it easily accessible to shareholders and potential new comers. The researcher felt that some of the requirements by the government, for example taxation and monetary policies regulating cooperatives were too stringent and that a review is necessary for a better environment to encourage growth of cooperatives.

The fear of resistance to change that had been a subject of study especially in strategic management for a long time has been embraced well; staff and management know that change is inevitable. However, resistance to change is a multifaceted phenomenon which introduces delays, additional costs and instabilities into the process of change. It may take the form of procrastination and delays in triggering the process of change.

\subsection{Discussions of Findings}

According to the findings above, it is evident that practice of SIM has its fair share of challenges. Right from planning/formulation and implementation of SIM, challenges do occur normally at certain stages. The leading challenges of SIM were competition, government policies and economic instability/recession. The findings also indicate that the least challenging factors affecting SIM were diversity (gender, ethnicity and status), business location and resistance to change. This was also consistent with findings by Owino (2011) who posited that location was regarded as a unique resource that was not easy to imitate. Thus competition is a major challenge for majority of cooperatives in fight for survival.

\subsection{SUMMARY, CONCLUSIONS AND RECOMMENDATIONS}

The findings reveal that the environment itself is dynamic and discontinuous and therefore SIM is necessary to enhance organizational preparedness in meeting novel turbulent challenges. The major aims of the study were to establish the challenges faced by cooperatives while practicing Strategic Issue Management. The study targeted 70 cooperatives; achieving $49 \%$ response rate with thirty four cooperatives returning the completed questionnaires.

The research objective of the study was to establish challenges faced in Strategic Issue Management in 
Savings and Credit Co-operatives in Mombasa County.

SIM cannot be exercised without a share of its challenges. According to Ansoff and McDonnell (1990), installation and acceptance of SIM is not likely to be simple. The difficulties come from different sources. Right from planning/formulation and implementation of SIM, challenges do occur normally at certain stages. This was consistent with this study where the researcher found out that some of the leading challenges of SIM were competition, government policies and economic instability/recession.

The findings also indicated that the least challenging factors affecting SIM were diversity (gender, ethnicity and status), business location and resistance to change. This was also consistent with findings by Owino (2011) who posited that location was regarded as a unique resource that was not easy to imitate. Thus competition is a major challenge for majority of cooperatives in fight for survival.

The researcher felt that some of the requirements by the government, exchange rates, politics, taxation and monetary policies regulating cooperatives were too stringent and that a review is necessary for a better environment to encourage growth of cooperatives.

Resistance to change is a multifaceted phenomenon which introduces delays, additional costs and instabilities into the process of change. It may take the form of procrastination and delays in triggering the process of change. There's nothing more difficult to take in hand, more perilous to implement, or more uncertain of success than to take a lead in the introduction of a novelty order of issues.

The acceptance of change as findings show in this study, confirms information in (Mwangi, 2008) fears that real time in managing strategic issues wrecks hierarchical organizations by making possible instant access to activities of all types, anywhere, anytime all the time. Refusal to take charge is frequently coupled with a mentality problem, a refusal by top management to accept new and unfamiliar issues as relevant to the enterprise. Thus the acceptance of SIM by top management is the major problem to solve.

Refusal of the top management group to submit itself to the discipline of SIM can be a taunting challenge. If top management pay a lip service to SIM, it will not work. In addition, these findings were consistent with Thompson, Strickland and Gamble (2007) who observed that consciously developing strategies constitutes a plan for coping with challenges and issues that stand as obstacles to the company's success. This was evidenced by findings in this study that confirmed that $73.53 \%$ of cooperatives in Mombasa County highly practiced Strategic Issue Management.

In conclusion, the fear of resistance to change that has been a subject of study especially in strategic management for a long time has been embraced well; staff and management know that change is inevitable. This might be the reason why many cooperatives viewed it as a least challenging factor. However, resistance to change is a multifaceted phenomenon which introduces delays, additional costs and instabilities into the process of change. It may take the form of procrastination and delays in triggering the process of change.

Cooperatives should realize they do not only compete against themselves, but also against other lenders such as banks, micro-finance institutions, mobile phone companies with their credit services, informal groupings and welfare associations. According to Owino (2011), it is recommended that cooperatives should merge in order to enrich their capital base and also compete in order to ward off threats from their more established common bigger rivals - commercial banks - whose loan arrangements are now almost favorable as those of cooperatives.

\subsection{Recommendations of the Study}

It is quite clear that Strategic Issue Management Practice has its fair share of challenges. Savings and credit cooperative societies have to be prepared for and be aware of the novel and known challenges if they want to be competitive in the turbulent business environment. They should also be informed that the leading challenges of SIM were competition, government policies and economic instability/recession while the least challenging factors affecting SIM were diversity (gender, ethnicity and status), business location and resistance to change.

\subsection{Suggestions for Further Research}

The researcher suggests that further research needs to be carried to confirm findings in this research that resistance to change has been well embraced (as exhibited by the low response that it was a challenging factor) and thus is not highly ranked as a major challenge in Strategic Issue Management.

More so, challenges of Strategic Issue Management are many and as technology advances with increase in human population, more and more novel challenges emerge. A case in point is the Corona Virus (Covid 19) world pandemic that started in China in 2019 and later affected the whole world, putting world economies to their knees. Thus more researches need to be carried out to establish more challenges affecting SIM in organizations. 


\subsection{Appendix 1: CHALLENGES OF STRATEGIC ISSUE MANAGEMENT}

To what extent do the following challenges affect Strategic Issue Management in your cooperative?

(Scale: 5=Very High; $\mathbf{4}=$ High; $\mathbf{3}=$ Moderate; $\mathbf{2}=$ Little; $\mathbf{1}=$ Not at all.)

\begin{tabular}{|c|c|c|c|c|c|}
\hline Challenges affecting SIM Practices & 1 & 2 & 3 & 4 & 5 \\
\hline Business location & & & & & \\
\hline Availability of financial resources & & & & & \\
\hline Adequate management competence & & & & & \\
\hline Government policies & & & & & \\
\hline Resistance to change & & & & & \\
\hline Culture & & & & & \\
\hline Constant changes in customer needs/demands & & & & & \\
\hline Implementation time frame & & & & & \\
\hline Technology & & & & & \\
\hline Competition & & & & & \\
\hline Motivation & & & & & \\
\hline Level of knowledge of employees & & & & & \\
\hline Ambiguity in vision and/or mission statement & & & & & \\
\hline Communication & & & & & \\
\hline Diversity (gender, ethnicity, status) & & & & & \\
\hline $\begin{array}{l}\text { Objective of the cooperative (profit maximization, social responsibility, market leadership, } \\
\text { quality leadership and survival) }\end{array}$ & & & & & \\
\hline Economic instability/recession & & & & & \\
\hline Foreign currency instability (Dollar) & & & & & \\
\hline
\end{tabular}

\section{References}

Amit, R. and Schoemaker, P.J.H. (1993). 'Strategic Assets and Organizational Rent', Strategic Management Journal, 14(1), pp.33-46.

Ansoff, H. I. \& McDonnell, E. (1990). Implanting Strategic Management. Prentice-Hall International.

Barney, J. (1986a).“Organizational Culture: Can it be a Source of Sustained Competitive Advantage?” Academy of Management Review, 11 (3), 1986a, pp. 656 -665.

Barney, J. (1991). "Firm Resources and Sustained Competitive Advantage." Journal of Management, 17(1): 99120. Available: http://www.ebscohost.com

Cooper, D. and Schindler, P. (2008). Business Research Methods (10 ${ }^{\text {th }}$ Ed.). Boston: McGraw-Hill International Edition.

Hesterly, W. S. and Barney, J. B. (2008). Strategic Management and Competitive Advantage: Concept and Cases: Pearce Prentice Hall.

Iriga, D. (2009). The Recession and the Sacco Movement. The Sacco Star. Issue 9, pp. 10-11.

Mkamunduli, S. A. (2005). Strategic Issue Management in the Insurance Companies in Kenya. Unpublished MBA Research Project Paper, University of Nairobi.

Mwangi, H. (2008). "Relationships between Competitive Strategies and Performances of Independent Oil Companies in Kenya". Unpublished MBA Project: UON.

Owino, M. (2011). Competitive Strategies Adopted by Savings and Credit Cooperatives in Mombasa County. Unpublished MBA Project: UON.

Thompson, S., Strickland, A. J. and Gamble, J. E. (2007). Crafting and Executing Strategy: The Quest for Competitive Advantage (Concepts and Cases). New York: McGraw-Hill Irwin.

Xolile, L. (2004). Testing the Suitability of Sacco's Current Strategies. Unpublished MBA Thesis, Faculty Management University of Kwazulu: Natal (Durban). 